\title{
Pengembangan Instrumen Asesmen Pengetahuan Fisika Berbasis Komputer untuk Meningkatkan Kesiapan Peserta Didik dalam Menghadapi Ujian Nasional Berbasis Komputer
}

\author{
Suyoso *, Edi Istiono, Subroto \\ ${ }^{1}$ Jurusan Pendidikan Fisika FMIPA UNY. Jl. Colombo No. 1, Karangmalang, Yogyakarta, Indonesia. \\ * Korespondensi Penulis. E-mail: suyososuyoso@gmail.com dan suyoso@uny.ac.id \\ Received:10 January 2017; Revised:10 March 2017; Accepted: 10 April 2017
}

\begin{abstract}
Abstrak
Penelitian ini bertujuan untuk 1) menghasilkan instrumen penilaian berbasis komputer yang layak untuk mengukur kemampuan kognitif peserta didik SMA, 2) menguji efektivitas instrumen penilaian berbasis komputer yang dikembangkan untuk mengukur pengetahuan Fisika peserta didik SMA, 3) mengukur tingkat kesiapan peserta didik dalam menghadapi ujian nasional berbasis komputer. Penelitian ini menggunakan model Research and Development $(R \& D)$ yang terdiri atas tiga tahap utama yaitu: tahap pendahuluan, tahap pengembangan dan tahap evaluasi. Pada tahap pendahuluan telah diidentifikasi permasalahan penilain pembelajaran fisika berbasis komputer. Tahap pengembangan telah dilakukan pembuatan desain instrumen peniliaian fisika berbasis komputer, validasi produk, revisi produk dan uji coba produk secara terbatas. Pada tahap evaluasi telah dilakukan uji coba secara luas, revisi produk, dan pembuatan produk akhir. Uji statistik deskritif digunakan untuk mendeskripsikan hasil aplikasi penilaian pengetahuan berbasis komputer. Hasil penelitian ini: (1) Instrumen soal yang dikembangkan layak untuk untuk mengukur kemampuan kognitif peserta didik SMA, (2) instrumen penilaian berbasis komputer lebih efektif dan efisien untuk mengukur kemampuan pengetahuan Fisika peserta didik SMA daripada paper and pencil test, (3) 58,67\% peserta didik sudah siap menghadapi tes berbasis komputer, $34 \%$ peserta didik belum siap melakukan tes berbasis komputer, dan 7,33\% tidak siap melakukan tes berbasis komputer.
\end{abstract}

Kata Kunci: Penilain berbasis Komputer, Fisika

\section{The Development of Computer-Based Assessment of Physics Science to Improve Readiness of Students in Dealing Computer-Based National Examanation}

\begin{abstract}
This research aims to 1) produce computer-based assessment instruments eligible to measure the cognitive abilities of senior high school students, 2) test the effectiveness of computer-based assessment instrument developed to measure the knowledge of physics in senior high school students, 3) measuring the level of readiness of students in dealing computer-based national examanation. This research uses a model of Research and Development $(R \& D)$ which consists of three main stages: the preliminary stage, the stage of development and evaluation phase. At the preliminary stage has been identified problems of computer-based assessment of learning physics. At the development stage has been carried out the design manufacture of computer-based assessment instrument physics, product validation, product revisions and testing of products on a limited basis. In the evaluation stage has been tested extensively, product revision, and the final product. Descriptive statistical test used to describe the results of the application of computer-based knowledge assessment. The results research show that : 1) computer-based assessment instruments eligible to measure cognitive abilities of senior high school students, 2) computer-based assessment instruments are more effective and efficient to measure the students knowledge of physics in senior high school rather than paper and pencil test, 3) $58.67 \%$ of students are ready to face computer-based test, $34 \%$ of students not yet ready for the computer based test and $7.33 \%$ are not ready to perform the test based computer.
\end{abstract}

Keywords: Computer-Based Assessment, Physics 
How to Cite: suyoso, s., Istiyono, E., \& Subroto, S. (2017). Pengembangan instrumen asesmen pengetahuan fisika berbasis komputer untuk meningkatkan kesiapan peserta didik dalam menghadapi ujian nasional berbasis komputer. Jurnal Pendidikan Matematika dan Sains, 5(1). doi:http://dx.doi.org/10.21831/jpms.v5i1.12461

Permalink/DOI: DOI: http://dx.doi.org/10.21831/jpms.v5i1.12461

\section{PENDAHULUAN}

Pengukuran dalam bidang pendidikan mencakup beberapa ranah, diantaranya: pengukuran ranah kognitif (pengetahuan), ranah afektif (sikap) dan ranah psikomotor (keterampilan). Biasanya, pengukuran pada ranah kognitif dila-kukan dengan tes. Ranah afektif diukur dengan kuesioner, wawancara dan pengamatan, sedang-kan ranah psikomotor diukur melalui penga-matan.

Dalam pelaksanaan pendidikan banyak keputusan yang harus dibuat oleh seorang guru antara lain yang menyangkut proses pembelajaran, hasil belajar dan seleksi bimbingan (Sudaryono, 2012, p.36). Untuk penelitian dengan objek manusia yang di dalamnya mencakup unsur variabel yang terkait dengan manusia, tes merupakan alat ukur yang sering ditemui di bidang penelitian pendidikan, psikologi maupun sosiologi. Dengan tes, seorang peneliti dapat mengukur konstruk yang diinginkan. Melalui indikator yang dipilih, seorang peneliti kemudian dapat mengidentifikasi konstruk yang hendak diukur (Sukardi, 2008, p.138). Indikatorindika-tor tersebut digunakan sebagai pedoman penyu-sunan instrumen penilaian.

Dalam penelitian pendidikan yang berkaitan dengan metode, pendekatan, strategi pembelajaran, dan kegiatan yang berkaitan dengan proses belajar mengajar sering direfleksikan sebagai variabel bebas, sedangkan yang merupakan variabel terikat di antaranya adalah pencapaian hasil belajar dan efektivitas program. Tes prestasi memiliki validitas dan reliabilitas yang tinggi sehingga sangat baik untuk mengukur kemam-puan kognitif peserta didik (Sparrow \& Davis, 2000, p.118), Oleh karena itu, wajar apabila tes prestasi banyak digunakan dalam penelitian maupun dalam pembahasan yang berkaitan erat dengan proses belajar mengajar.

Dari hasil wawancara yang dilakukan dengan beberapa guru fisika Sekolah Menengah Atas (SMA) di Daerah Istimewa Yogyakarta dan sebagian di daerah Provinsi Jawa Tengah, seka-rang ini instrumen penilaian yang biasa digu-nakan berupa tes objektif pilihan majemuk atau tes uraian yang dikerjakan di kertas. Hal ini disebabkan karena adanya kecenderungan mempertahankan kebiasaan lama, menulis di kertas. Guru belum tergerak untuk menerapkan penilaian berbantuan komputer atau computerized based test.

Computerized based test merupakan sistem ujian dengan memanfaatkan teknologi komputer sebagai media tes. Hernawati (2007, p.3) menyatakan bahwa computerized based test memiliki beberapa kelebihan, diantaranya: mengurangi waktu untuk pekerjaan penilaian tes dan membuat laporan tertulis, menghilangkan pekerjaan logistik seperti mendistribusikan, menyimpan dan tes menggunakan kertas. Selain itu hasil penilaian dapat langsung dilihat setelah penilaian dilakukan sehingga mengurangi beban guru dalam mengoreksi jawaban peserta didik. Selain itu, berdasarkan penelitian oleh Özden, Erturk, \& Sanli (2004) peserta didik memberikan tanggapan yang positif terhadap tes berbasis komputer. Selain itu, tes berbasis komputer juga akurat untuk mengukur peserta tes dengan kemampuan sedang sampai tinggi (Santoso, 2010)

Berdasarkan hasil observasi pada beberapa SMA di Daerah Istimewa Yogyakarta, sebagian besar sekolah sudah memiliki fasilitas yang layak untuk melakukan tes berbasis komputer. Hal ini dipicu adanya ujian nasional dilakukan berbasis komputer. Walau pada akhirnya belum diimple-mentasikan secara menyeluruh, akan tetapi seba-gian besar sekolah sudah memiliki sarana dan prasarana yang memadai untuk melakukan tes berbasis komputer.

Berdasarkan uraian tersebut, perlu dikembangkan instrumen penilaian berbasis komputer untuk meningkatkan kesiapan peserta didik dalam menghadapi ujian nasional berbasis komputer. Dengan demikian tujuan penelitian ini adalah untuk 1) menghasilkan instrumen penilaian berbasis komputer yang layak untuk mengukur kemampuan kognitif peserta didik SMA, 2) menguji efektivitas instrumen penilaian berbasis komputer yang dikembangkan untuk mengukur pengetahuan Fisika peserta didik SMA, dan 3) mengukur tingkat kesiapan peserta didik dalam menghadapi ujian nasional berbasis komputer. 
Dengan adanya penelitian ini diharap-kan peserta didik lebih mengenal berbagai ma-cam penilaian berbasis komputer sehingga ketika menghadapi ujian berbasis komputer sudah tidak canggung lagi.

\section{METODE}

\section{Jenis Penelitian}

Jenis Penelitian ini menggunakan desain Research and Development $(R \& D)$. Metode penelitian dan pengembangan adalah metode penelitian yang digunakan untuk menghasilkan produk tertentu dan menguji keefektifan produk tersebut (Sugiyono, 2011, p.333). Model $R \& D$ terdiri atas tiga tahap utama yaitu: tahap pendahu-luan, tahap pengembangan dan tahap evaluasi.

\section{Tempat, Waktu dan Subyek Penelitian}

Penelitian ini dilaksanakan di SMAN 4 Yogyakarta, SMAN 5 Yogyakarta, SMAN 6 Yogyakarta, dan SMAN 11 Yogyakarta. Penelitian dilakukan pada bulan Mei sampai Juni 2016. Subyek penelitian ini adalah peserta didik kelas XI SMA yang telah menerima materi teori kinetik gas. Pada subjek uji coba terbatas dilakukan di SMAN 6 Yogyakarta dengan jumlah sekitar 100 orang peserta didik. Subyek uji coba skala luas dilakukan di SMAN 4 Yogyakarta, SMAN 5 Yogyakarta, SMAN 6 Yogyakarta, dan SMAN 11 Yogyakarta dengan jumlah subyek sekitar 300 orang peserta didik.

\section{Intrumen Penelitian}

\section{Kisi-kisi Soal}

Kisi-kisi soal disusun berdasarkan pada Kurikulum 2013, pada mata pelajaran fisika SMA Kelas XI tahun pelajaran 2015/2016. Pokok bahasan fluida dan teori kinetik gas semester genap yang mengarah pada kemampuan kognitif peserta didik. Soal berbentuk pilihan ganda yang terdiri dari dua paket dengan delapan anchor item (soal yang sama pada kedua paket). Soal pilihan ganda terkemas dalam aplikasi Flash untuk materi fluida dan Quizstar untuk materi teori kinetik gas.

\section{Lembar Validasi Instrumen}

Lembar validasi digunakan untuk melakukan penilaian oleh dosen ahli terhadap instrumen penilaian yang dikembangkan. Saran yang diberikan oleh validator menjadi dasar dilakukan perbaikan pada instrumen penilaian yang dikembangkan.

\section{Angket Respon Peserta Didik dan Guru}

Angket ini merupakan instrumen yang berisi pendapat para pengguna, yakni guru dan peserta didik yang bersangkutan. Angket ini bertujuan untuk mengetahui respon pengguna terhadap aplikasi Flash dan Quizstar.

\section{Teknik Analisis Data}

\section{Validitas Isi Soal}

Validitas isi butir soal dapat ditunjukkan dengan statistik yang diusulkan oleh Aiken (1985) dalam Syaifuddin Azwar (2015, pp. 112114). Formula $V$ Aiken dirumuskan sebagai berikut:

$$
V=\frac{\sum s}{[n(c-1)]}
$$

$$
\begin{aligned}
& \text { Keterangan: } \\
& V=\text { koefisien validitas isi } \\
& n \quad=\text { banyak penilai } \\
& s \quad=r \text { - lo } \\
& r \quad=\text { angka yang diberikan seorang penilai } \\
& l o=\text { angka penilaian validitas terendah } \\
& c \quad=\text { angka penilaian validitas tertinggi } \\
& \text { Besar nilai V menunjukkan nilai koefisien }
\end{aligned}
$$
validitas instrumen yang diukur. Butir soal dikatakan memiliki validitas isi yang baik dan mendukung validitas isi tes secara keseluruhan apabila nilai $V$ lebih dari 0,5 .

\section{Validitas Soal}

\section{Kecocokan Butir Soal dengan Model PCM}

Penetapan fit butir soal secara keseluruhan dan fit peserta didik secara keseluruhan dikem-bangkan Adam \& Khoo (1996, p. 28) berdasar-kan nilai rata-rata INFIT MNSQ (INFIT Mean of Square) beserta simpangan bakunya. Jika rata-rata INFIT MNSQ sekitar 1 dan simpangan baku-nya 0, maka keseluruhan tes fit dengan model.

Penetapan fit tiap butir soal mengikuti kaidah bahwa Item characteritic curve (ICC) akan mendatar (flat) bila besarnya INFIT MNSQ untuk butir soal atau $e$ lebih besar dari satuan logit $>1,30$ atau $<0,77$. Oleh karena itu, dalam program Quest suatu butir soal atau peserta didik fit terhadap model jika nilai INFIT MNSQ antara 0,77 sampai 1,30.

\section{Reliabilitas}

Estimasi reliabilitas menurut IRT (Item Response Theory) dihitung berdasarkan peserta 
didik disebut dengan indeks sparasi person. Semakin tinggi indeks sparasi person semakin konsisten setiap butir soal pengukur digunakan untuk mengukur peserta didik yang bersangkutan sehingga disebut reliabilitas tes (Subali, 2011, p. 11). Adapun klasifikasi reliabilitas soal disajikan dalam Tabel 1.

Tabel 1. Tingkat Reliabilitas Berdasarkan Nilai Alpha

\begin{tabular}{cc}
\hline Alpha & Tingkat Reliabilitas \\
\hline 0,00 s.d. 0,19 & Kurang Reliabel \\
0,20 s.d. 0,39 & Agak Reliabel \\
0,40 s.d. 0,59 & Cukup Reliabel \\
0,60 s.d. 0,79 & Reliabel \\
0,80 s.d. 1,00 & Sangat Reliabel \\
\hline
\end{tabular}

Tingkat Kesukaran Butir Soal

Tingkat kesukaran butir soal diperoleh dari interpretasi program Quest pada nilai threshold di lihat dari item estimates. Menurut Hambleton \& Swaminathan (1985, p. 36), tingkat kesukaran bernilai baik jika berada pada rentang -2 sampai +2 .

\section{Fungsi Informasi dan SEM}

Untuk mendapatkan fungsi informasi dan SEM digunakan program Bilog. Berdasarkan fungsi informasi dan SEM, maka tes cocok untuk peserta didik dengan rentang kemampuan $(\theta)$ tertentu.

\section{Kelayakan Media Penilaian Berbasis Quizstar} (CVR)

Menghitung nilai Content Validity Ratio

$$
C V R=\frac{\left(N_{e}-\frac{N}{2}\right)}{\frac{N}{2}}
$$

(Lawshe, 1975, p. 567)

$N_{e}=$ jumlah validator yang menyetujui

$N=$ jumlah total validator

Menghitung nilai Content Validity Index (CVI)

$$
C V I=\frac{\text { jumlah CVR }}{\text { jumlah butir angket }}
$$

Rentang hasil nilai CVR dan CVI adalah $-1<0$ $<$ 1. Angka tersebut dikategorikan sebagai berikut.

$$
\begin{array}{lll}
-1<\mathrm{x}<0 & =\text { tidak baik } \\
0 & =\text { baik } \\
0<\mathrm{x}<1 & =\text { sangat baik } & \text { (Lawshe, 1975) }
\end{array}
$$

Reliabilitas instrumen media ditentukan dengan mencari Interclass Correlation Coefficient (ICC). Nilai ICC dianalisis dengan SPSS versi 23. Fleiss (Craven \& Morris, 2010, p. 210) mengkategorikan tingkat reliabilitas menjadi beberapa kategori yang disajikan pada Tabel 2 .

Tabel 2. Nilai ICC dan Klasifikasi

\begin{tabular}{cc}
\hline Nilai ICC & Klasifikasi \\
\hline$<0,40$ & Kurang Reliabel \\
$0,40-0,75$ & Reliabel \\
$>0,75$ & Sangat Reliabel \\
\hline
\end{tabular}

\section{Angket Respon Peserta Didik}

Data berupa nilai yang terkumpul dari angket angket respon peserta didik dikonversikan menjadi data kuantitatif. Menurut Azwar (1998: 163) lima level kemampuan memiliki rentang seperti dinyatakan pada Tabel 3

Tabel 3. Rentang Lima Level Kemamampuan

\begin{tabular}{cc}
\hline Interval Kemampuan & Level \\
\hline$M_{i}+1,5 S B_{i}<\theta$ & Sangat Tinggi \\
$M_{i}+0,5 S B_{i}<\theta \leq M_{i}+1,5 S B_{i}$ & Tinggi \\
$M_{i}-0,5 S B_{i}<\theta \leq M_{i}+0,5 S B_{i}$ & Sedang \\
$M_{i}-1,5 S B_{i}<\theta \leq M_{i}-0,5 S B_{i}$ & Rendah \\
$\theta<M_{i}-1,5 S B_{i}$ & Sangat Rendah \\
\hline
\end{tabular}

\section{HASIL DAN PEMBAHASAN}

\section{Hasil Penelitian}

Hasil penelitian meliputi hasil estimasi butir soal dan testi baik pada uji coba terbatas maupun hasil uji coba skala luas. Hasil estimasi tersebut digunakan untuk mendeskripsikan kuali-tas dan kelayakan perangkat tes yang dikem-bangkan. Hasil estimasi butir soal dan testi pada uji coba terbatas dan skala luas untuk perangkat tes berbasis Flash dan Quizstar dapat dilihat pada Tabel 4 sampai Tabel 7.

Tabel 4. Hasil Estimasi untuk Butir Soal dan Testi menurut Model PCM Hasil Uji Coba Terbatas berbasis Flash

\begin{tabular}{lcc}
\hline \multicolumn{1}{c}{ Uraian } & $\begin{array}{c}\text { Estimasi } \\
\text { untuk item }\end{array}$ & $\begin{array}{c}\text { Estimasi } \\
\text { untuk testi }\end{array}$ \\
\hline $\begin{array}{l}\text { Nilai rata-rata } \\
\text { dan simpangan } \\
\text { baku }\end{array}$ & $0,00 \pm 0,99$ & $-0,89 \pm 0,43$ \\
\hline $\begin{array}{l}\text { Nilai rata-rata } \\
\text { dan simpangan } \\
\text { baku yang sudah } \\
\text { disesuaikan }\end{array}$ & $0,00 \pm 0,96$ & $-0,89 \pm 0,32$ \\
\hline Reliabilitas & 0,94 & \\
\hline Nilai rata-rata & $1,00 \pm 0,04$ & $1,00 \pm 0,11$ \\
\hline
\end{tabular}


Jurnal Pendidikan Matematika dan Sains, V (1), 2017, 93

Suyoso, Edi Istiono, Subroto

\begin{tabular}{llc}
\hline \multicolumn{1}{c}{ Uraian } & $\begin{array}{c}\text { Estimasi } \\
\text { untuk item }\end{array}$ & $\begin{array}{c}\text { Estimasi } \\
\text { untuk testi }\end{array}$ \\
\hline $\begin{array}{l}\text { dan simpangan } \\
\text { baku INFIT } \\
\text { MNSQ }\end{array}$ & & \\
\hline $\begin{array}{l}\text { Nilai rata-rata } \\
\text { dan simpangan } \\
\text { baku OUTFIT }\end{array}$ & $1,00 \pm 0,30$ & $0,99 \pm 0,18$ \\
MNSQ & & \\
\hline $\begin{array}{l}\text { Nilai rata-rata } \\
\text { dan simpangan } \\
\text { baku INFIT t }\end{array}$ & $0,04 \pm 0,39$ & $0,04 \pm 0,54$ \\
\hline $\begin{array}{l}\text { Nilai rata-rata } \\
\text { dan simpangan } \\
\text { baku OUTFIT t }\end{array}$ & $0,99 \pm 0,08$ & $0,00 \pm 0,74$ \\
\hline
\end{tabular}

Tabel 5. Hasil Estimasi untuk Butir Soal dan

Testi menurut Model PCM Hasil Uji Coba

Terbatas berbasis Quizstar

\begin{tabular}{lcc}
\hline \multicolumn{1}{c}{ Uraian } & $\begin{array}{c}\text { Estimasi } \\
\text { untuk item }\end{array}$ & $\begin{array}{c}\text { Estimasi } \\
\text { untuk item }\end{array}$ \\
\hline $\begin{array}{l}\text { Nilai rata-rata } \\
\text { dan simpangan } \\
\text { baku }\end{array}$ & $0,00 \pm 0,86$ & $-0,76 \pm 0,52$ \\
\hline $\begin{array}{l}\text { Nilai rata-rata } \\
\text { dan simpangan } \\
\text { baku yang sudah } \\
\text { disesuaikan }\end{array}$ & $0,00 \pm 0,83$ & $-0,76 \pm 0,45$ \\
\hline $\begin{array}{l}\text { Reliabilitas } \\
\text { Nilai rata-rata } \\
\text { dan simpangan } \\
\text { baku INFIT }\end{array}$ & 0,93 & \\
MNSQ & $1,00 \pm 0,04$ & $1,00 \pm 0,10$ \\
\hline $\begin{array}{l}\text { Nilai rata-rata } \\
\text { dan simpangan } \\
\text { baku OUTFIT } \\
\text { MNSQ }\end{array}$ & $1,00 \pm 0,07$ & $1,00 \pm 0,22$ \\
\hline $\begin{array}{l}\text { Nilai rata-rata } \\
\text { dan simpangan } \\
\text { baku INFIT t }\end{array}$ & $0,12 \pm 0,60$ & $0,01 \pm 0,99$ \\
\hline $\begin{array}{l}\text { Nilai rata-rata } \\
\text { dan simpangan } \\
\text { baku OUTFIT t }\end{array}$ & $0,05 \pm 0,49$ & $-0,03 \pm 0,83$ \\
\hline \multicolumn{1}{c}{$\begin{array}{l}\text { Tabel 6. Hasil Estimasi untuk Butir Soal dan } \\
\text { Testi menurut Model } P C M \text { Hasil Uji Coba Luas } \\
\text { berbasis Flash }\end{array}$} & \\
\hline $\begin{array}{l}\text { Nilai rata-rata } \\
\text { dan simpangan } \\
\text { baku }\end{array}$ & $0,00 \pm 0,98$ & $-0,89 \pm 0,41$ \\
\hline & & \\
\hline & & \\
\hline & & \\
\hline & & \\
\hline
\end{tabular}

\begin{tabular}{lll}
\hline \multicolumn{1}{c}{ Uraian } & \multicolumn{1}{c}{$\begin{array}{c}\text { Estimasi } \\
\text { untuk item }\end{array}$} & $\begin{array}{c}\text { Estimasi } \\
\text { untuk testi }\end{array}$ \\
\hline $\begin{array}{l}\text { Nilai rata-rata } \\
\text { dan simpangan } \\
\text { baku yang sudah } \\
\text { disesuaikan }\end{array}$ & $0,00 \pm 0,95$ & $-0,89 \pm 0,30$ \\
\hline Reliabilitas & 0,94 & 0,53 \\
\hline $\begin{array}{l}\text { Nilai rata-rata } \\
\text { dan simpangan } \\
\text { baku INFIT }\end{array}$ & $1,00 \pm 0,04$ & $1,00 \pm 0,12$ \\
MNSQ & & \\
\hline $\begin{array}{l}\text { Nilai rata-rata } \\
\text { dan simpangan } \\
\text { baku OUTFIT } \\
\text { MNSQ }\end{array}$ & $1,00 \pm 0,07$ & $1,00 \pm 0,21$ \\
\hline $\begin{array}{l}\text { Nilai rata-rata } \\
\text { dan simpangan } \\
\text { baku INFIT t }\end{array}$ & $0,08 \pm 0,48$ & $0,02 \pm 0,93$ \\
\hline $\begin{array}{l}\text { Nilai rata-rata } \\
\text { dan simpangan } \\
\text { baku OUTFIT t }\end{array}$ & $0,04 \pm 0,40$ & $0,00 \pm 0,85$ \\
\hline
\end{tabular}

Tabel 7. Hasil Estimasi untuk Butir Soal dan

Testi menurut Model PCM Hasil Uji Coba Luas berbasis Quizstar

\begin{tabular}{lll}
\hline \multicolumn{1}{c}{ Uraian } & $\begin{array}{c}\text { Estimasi } \\
\text { untuk item }\end{array}$ & $\begin{array}{c}\text { Estimasi } \\
\text { untuk testi }\end{array}$ \\
\hline $\begin{array}{l}\text { Nilai rata-rata } \\
\text { dan simpangan } \\
\text { baku }\end{array}$ & $0,00 \pm 0,72$ & $-0,95 \pm 0,52$ \\
\hline $\begin{array}{l}\text { Nilai rata-rata } \\
\text { dan simpangan } \\
\text { baku yang sudah } \\
\text { disesuaikan }\end{array}$ & $0,00 \pm 0,71$ & $-0,95 \pm 0,44$ \\
\hline Reliabilitas & 0,96 & \\
\hline $\begin{array}{l}\text { Nilai rata-rata } \\
\text { dan simpangan } \\
\text { baku INFIT }\end{array}$ & $1,00 \pm 0,04$ & $1,00 \pm 0,07$ \\
MNSQ & & \\
\hline $\begin{array}{l}\text { Nilai rata-rata } \\
\text { dan simpangan } \\
\text { baku OUTFIT } \\
\text { MNSQ }\end{array}$ & $1,00 \pm 0,10$ & $1,00 \pm 0,15$ \\
\hline $\begin{array}{l}\text { Nilai rata-rata } \\
\text { dan simpangan } \\
\text { baku INFIT t }\end{array}$ & $0,02 \pm 0,86$ & \\
\hline $\begin{array}{l}\text { Nilai rata-rata } \\
\text { dan simpangan } \\
\text { baku OUTFIT t }\end{array}$ & $0,03 \pm 0,79$ & $0,05 \pm 0,60$ \\
\hline & & \\
\hline
\end{tabular}


Jurnal Pendidikan Matematika dan Sains, V (1), 2017, 94

Suyoso, Edi Istiono, Subroto

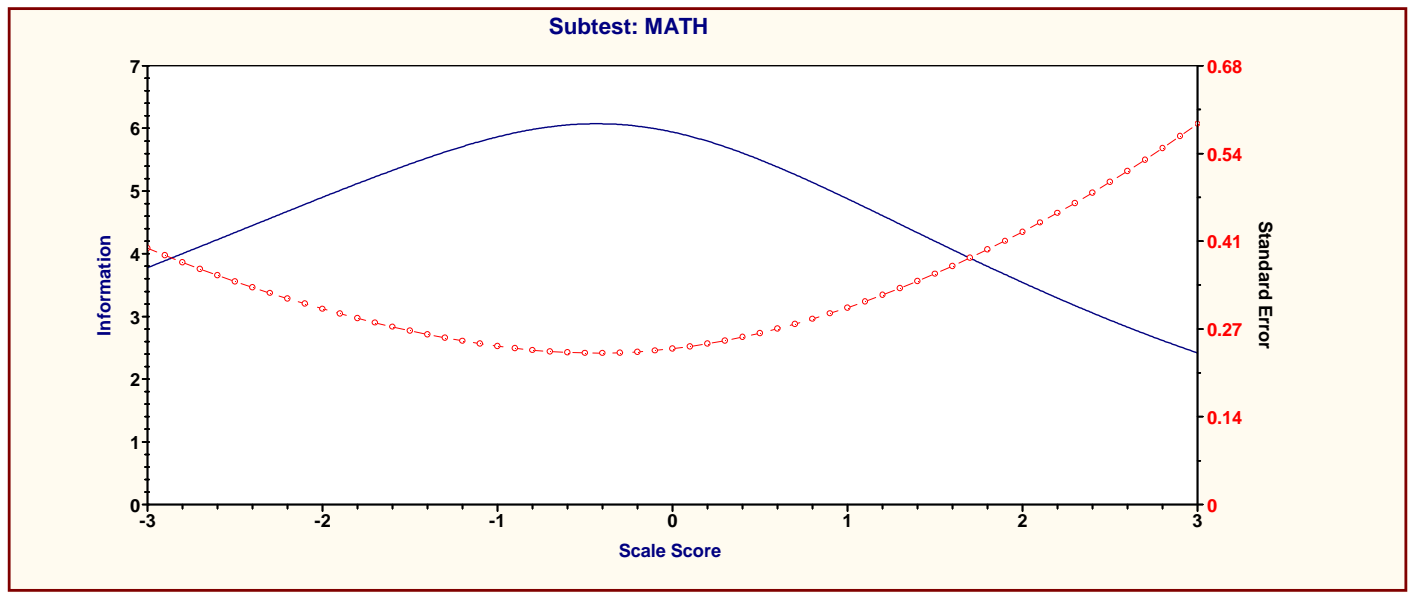

Gambar 1. Fungsi Informasi dan SEM pada Uji Coba Terbatas Berbasis Flash

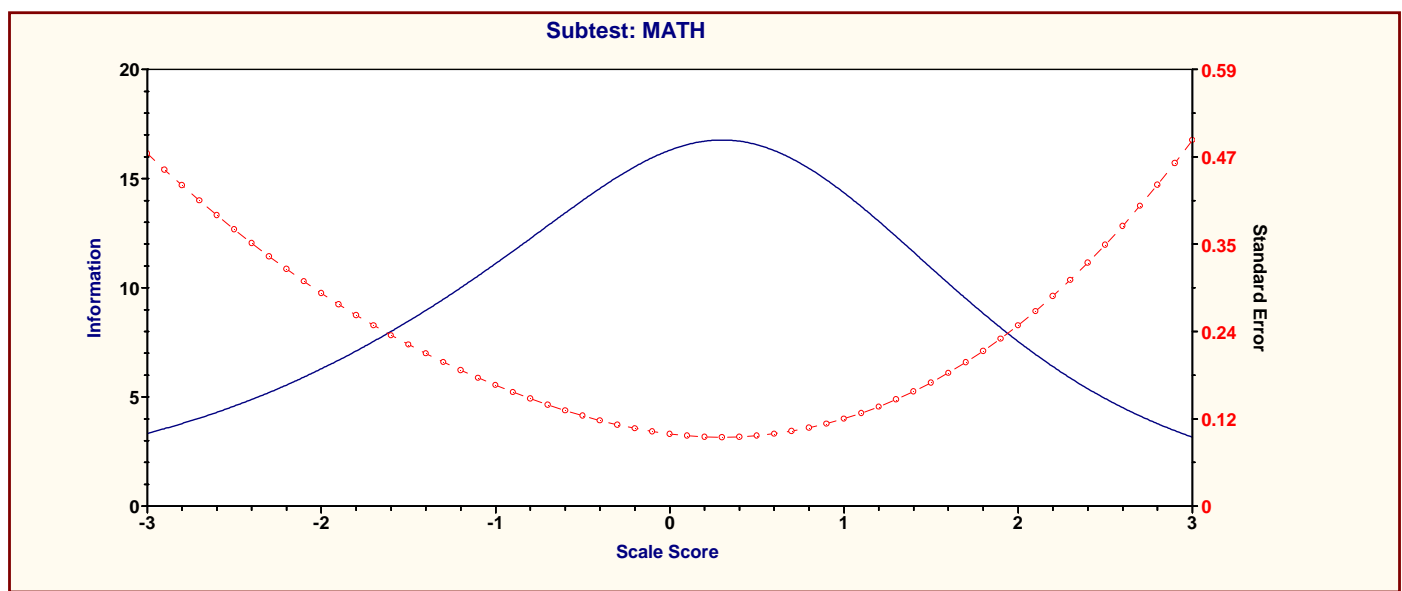

Gambar 2. Fungsi Informasi dan SEM pada Uji Coba Luash Berbasis Flash

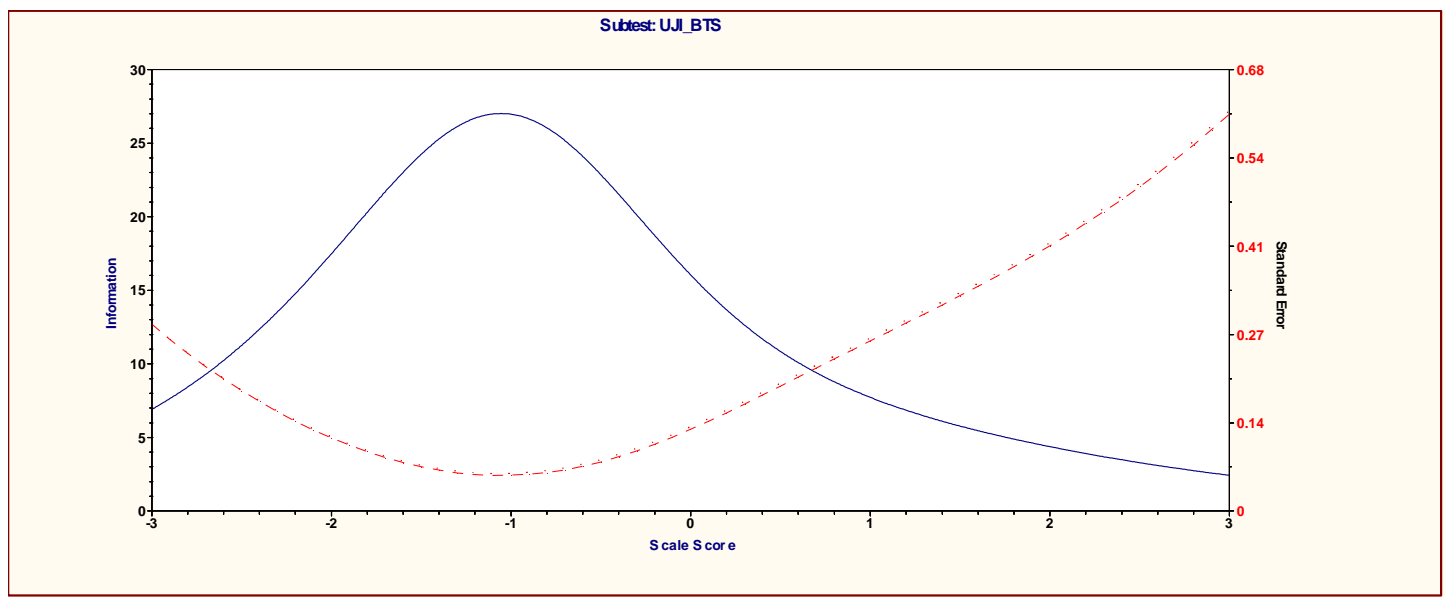

Gambar 3. Fungsi Informasi dan SEM pada Uji Coba Terbatas Berbasis Quizstar 


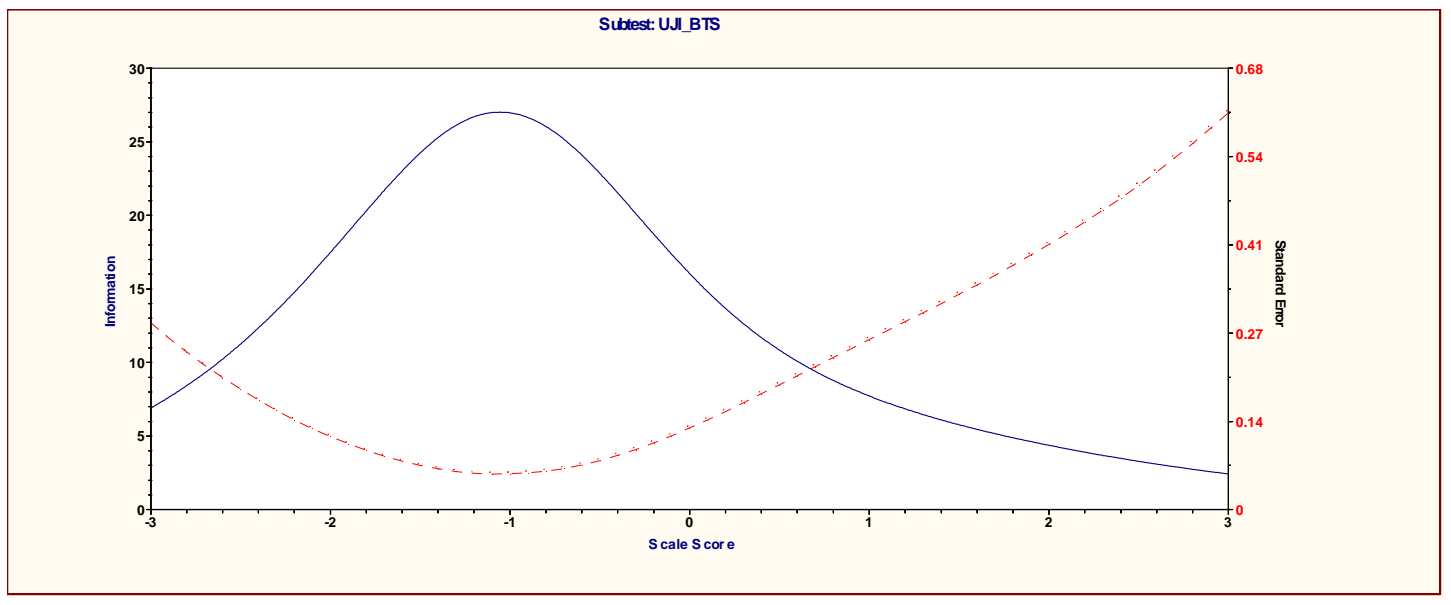

Gambar 4. Fungsi Informasi dan SEM pada Uji Coba Luas Berbasis Quizstar

\section{Pembahasan}

Analisis Soal pada materi Fluida

Analisis uji terbatas menggunakan program Quest dan Bilog. Program Quest digunakan untuk mencari nilai INFIT MNSQ, nilai ini merupakan informasi diterima atau ditolaknya butir soal yang dikembangkan. Berdasarkan nilai INFIT MNSQ butir-butir yang dikembangkan terletak pada nilai diantara 0,98 sampai dengan 1,05. Butir dikatakan baik jika nilai INFIT MNSQ terletak antara 0,77 sampai dengan 1,30 (Adam \& Khoo, 1996: 28), dengan demikian semua butir berdasarkan kriteria ini fit atau dapat diterima berdasarkan nilai INFIT $M N S Q$ pada output program Quest.

Program Bilog digunakan untuk mencari grafik fungsi informasi dan standard error measurement (SEM). Berdasarkan fungsi informasi dan SEM yang dinyatakan dengan Gambar 1 instrumen yang dikembangkan cocok untuk peserta didik dengan tingkat kemampuan $(\theta)$ antara -2,7 sampai dengan 1,7.

Berdasarkan analisis hasil uji coba luas menggunakan program Quest, difficulty butirbutir terletak antara $-2,80$ sampai 1,32 . Tingkat kesukaran (b) di luar batas $-2,0 \leq \mathrm{b} \leq 2,0$ adalah butir kurang baik menurut Hambleton \& Swaminathan (1991, p. 34). Oleh karena itu dilakukan eliminasi butir soal yang memiliki tingkat kesukaran kurang dari -2,0. Butir-butir yang memiliki nilai tingkat kesukaran kurang dari -2,0 adalah butir nomor 35, 38 dan 39 atau butir nomor 3, 25 dan 32 baik soal paket A ataupun paket B. Tiga butir soal tersebut merupakan anchor item. Berdasarkan nilai INFIT MNSQ butir-butir yang dikembangkan terletak pada nilai diantara 0,87 sampai dengan 1,12. Butir dikatakan baik jika nilai INFIT MNSQ terletak antara 0,77 sampai dengan 1,30
(Adam \& Khoo, 1996, p. 28), dengan demikian semua butir berdasarkan kriteria ini fit.

Program Bilog digunakan untuk mencari grafik fungsi informasi dan standard error measurement (SEM). Berdasarkan fungsi informasi dan SEM yang dinyatakan dengan Gambar 2 Instrumen yang dikembangkan cocok untuk peserta didik dengan tingkat kemampuan $(\theta)$ antara -1,6 sampai dengan 2,0.

\section{Analisis Soal pada materi Teori Kinetik Gas}

Analisis uji terbatas menggunakan program Quest dan Bilog. Program Quest digunakan untuk mencari nilai INFIT MNSQ. Berdasarkan nilai INFIT MNSQ butir-butir yang dikem-bangkan terletak pada nilai diantara 0,90 sampai dengan 1,08. Butir dikatakan baik jika nilai INFIT MNSQ terletak antara 0,77 sampai dengan 1,30 (Adam \& Khoo, 1996, p. 28), dengan demikian semua butir berdasarkan kriteria ini fit.

Program Bilog digunakan untuk mencari grafik fungsi informasi dan standard error measurement (SEM). Berdasarkan fungsi informasi dan SEM yang dinyatakan dengan Gambar 3 . Instrumen yang dikembangkan cocok untuk peserta didik dengan tingkat kemampuan $(\theta)$ antara -2,8 sampai dengan 1,7.

Berdasarkan analisis hasil uji coba luas menggunakan program Quest, difficulty butirbutir terletak antara $-1,99$ sampai 1,83 . Tingkat kesukaran (b) di luar batas $-2,0 \leq \mathrm{b} \leq 2,0$ adalah butir kurang baik menurut Hambleton \& Swaminathan (1991, p. 34). Berdasarkan nilai INFIT MNSQ butir-butir yang dikembangkan terletak pada nilai diantara 0,93 sampai dengan 1,09. Butir dikatakan baik jika nilai INFIT $M N S Q$ terletak antara 0,77 sampai dengan 1,30 
(Adam \& Khoo, 1996, p. 28), dengan demikian semua butir berdasarkan kriteria ini fit.

Program Bilog digunakan untuk mencari grafik fungsi informasi dan standard error measurement (SEM). Berdasarkan fungsi informasi dan SEM yang dinyatakan dengan Gambar 4. Instrumen yang dikembangkan cocok untuk peserta didik dengan tingkat kemampuan $(\theta)$ antara -2,3 sampai dengan 1,1. Rentang kemampuan peserta didik tersebut termasuk dalam kategori sedang.

\section{Penilaian Media}

Aplikasi penilaian berbasis flash dan Quizstar berdasarkan penilaian dari guru mendapatkan nilai CVI sebesar 1,00 yang termasuk kategori sangat baik. Aplikasi berdasarkan analisis persentase kelayakan dari angket respon peserta didik didapatkan kategori sangat baik, baik, kurang baik dan tidak baik berturut-turut $33,94 \%, 63,82 \%, 6,79 \%$, dan $0,41 \%$.

\section{Kesiapan Peserta Didik Menghadapi Tes Berbasis Komputer}

Penetapan fit testi secara keseluruhan juga dapat dilihat dari rata-rata nilai infitMNSQ beserta simpangan bakunya (Adam \& Kho, 1996). Pada analisis uji terbatas nilai rata-rata infitMNSQ sebesar 1,00 dengan standar deviasi sebesar 0,12 untuk macromedia dan rata-rata 1,00 dengan 0,07 untuk Quizstar. Sedangkan pada uji luas diperoleh nilai rata-rata infitMNSQ sebesar 1,00 dengan standar deviasi sebesar 0,13 untuk macromedia dan rata-rata 1,00 dengan standar deviasi 0,10 untuk Quizstar.

Hasil analisis nilai infitMNSQ untuk testi merepresentasikan bahwa peserta didik lebih siap mengerjakan tes berbasis paper and pencil test daripada tes berbasis komputer karena standar deviasi pada uji luas (berbasis komputer) lebih besar daripada uji terbatas (paper and pencil test). Berdasarkan hasil tersebut juga diketahui pening-katan kesiapan peserta didik dalam melakukan tes berbasis komputer dilihat dari penurunan standar deviasi tes berbasis Quizstar (dilakukan setelah tes berbasis macromedia) jika diban-dingkan dengan tes berbasis macromedia. Selain itu berdasarkan angket peserta didik $34 \%$ peserta didik belum siap melakukan tes berbasis kom-puter dan 7,33 $\%$ tidak siap melakukan ters ber-basis komputer. Dengan adanya pengembangan instrumen berbasis komputer peserta didik mengenal berbagai macam bentuk tes berbasis komputer dan meningkatkan kesiapan meng-hadapi tes berbasis komputer.

\section{SIMPULAN}

Berdasarkan hasil penelitin dan analisis terhadap temuan-temuan selama penelitian, maka diperoleh kesimpulan yaitu (1) instrumen soal yang dikembangkan layak untuk untuk mengukur kemampuan kognitif karena telah memenuhi validitas isi dengan expert judgment dan telah mendapatkan bukti empiris fit dengan model PCM; (2) aplikasi penilaian berbasis komputer lebih efektis danefisien dibandingkan dengan penilaian berbasis paper and pencil test; dan (3) $58,67 \%$ peserta didik sudah siap menghadapi tes berbantuan komputer ,34\% peserta didik belum siap melakukan tes berbasis komputer dan $7,33 \%$ tidak siap melakukan tes berbasis komputer.

Kendala utama yang dihadapi dalam pelaksanaan penilaian berbasis komputer yaitu keterbatasan fasilitas penunjang seperti komputer, maka dalam hal ini pemerintah hendaknya dapat memberikan bantuan untuk memenuhi kebutuhan tersebut, agar proses penilaian berbasis komputer ini dapat dilakukan secara merata. Untuk penelitian di masa yang akan datang, hendaknya dilaksanakan penelitian serupa pada mata pelajaran lainnya dan pada setiap jenjang, sehingga kedepannya perangkat tes berbasis komputer akan semakin banyak tersedia dan dapat mempermudah guru untuk melaksanakan penilaian berbasis komputer pada mata pelajaran dan jenjang lainnya.

\section{DAFTAR PUSTAKA}

Azwar, S. (2015). Reliabilitas dan validitas. Yogyakarta: Pustaka Pelajar.

Adams, R. J., \& Khoo, S. T. (1996). Quest: The interactive test analysis system version 2.1. Victoria: The Australian Council for Educational Reearch

Craven, B. C., \& Morris, A. R. (2010). Modified ashworth scale reliability for measurement of lower extremity spasticity among patients with SCI. Spinal Cord, 48, 207213.

Sudaryono. (2012). Dasar-dasar evaluasi pembelajaran. Yogyakarta: Graha Ilmu

Hambleton, R. K., \& Swaminathan, H. (1985). Item respon theory: Principles and 
Aplications. Boston, MA: Kluwer Nijhoff Publishing

Hernawati, K. (2007). Evaluasi dan penilaian interaktif berbasis web. Skripsi tidak diterbitkan. Yogyakarta: FMIPA Universitas Negeri Yogyakarta.

Lawshe, C.H. (1975). A quantitative approach to content validity. Personnel Psychology, 28, 563-575.

Özden, M. Y., Erturk, I., \& Sanli, R. (2004). Students' perception of online assessment: A case study. Journal of Distance Education, 19, 77-93.

Sparrow, S. S. \& Davis, S. M. (2010). Recent advances in assessment of intelligence and cognition. Journal of Children Psychology Psychiat, 41 (1), 117-131.

Santoso, A. (2010). Pengembangan computerized adaptive testing untuk mengukur hasil belajar mahasiswa
Universitas Terbuka. Jurnal Penelitian dan Evaluasi Pendidikan, 14 (1), 62 - 83.

Subali, B. (2011). Panduan analisis data pengukuran pendidikan untuk memperoleh bukti empirik kesahihan menggunakan program Quest. Yogyakarta: Lembaga Penelitian dan Pengabdian pada Masyarakat UNY.

Sugiyono. (2011). Metode penelitian administrasi dilengkapi dengan metode $R \& D$. Bandung: Alfabeta

\section{PROFIL SINGKAT}

Suyoso, lahir di Klaten, 10 Juni 1953, S1 Pendidikkan Fisika IKIP Semarang (UNES)lulus tahun 1980, S2 Fisika UGM lulus tahun 1994, dosen Jurusan Pendidikan Fisika FMIPA

UNY. 